\title{
THE OCEAN PLANET \\ Plenary Address to the ANZAAS Conference, Hobart, 30 September 1998
}

\author{
by Dr Nan Bray \\ Chief of CSIRO Marine Research
}

\begin{abstract}
Bray, N., 2000 (31:v): The Ocean Planet: Plenary Address to the ANZAAS Science Conference, Hobart, 30 September 1998. In Banks, M.R. \& Brown, M.J. (Eds): TASMANIA AND THE SOUTHERNOCEAN. Pap. Proc. R. Soc. Tasm. 133(3): 1-3. https://doi.org/10.26749/rstpp.133.2.1 ISSN 0080-4703. CSIRO Marine Research, GPO Box 1538, Hobart, Tasmania, Australia 7001.

The economic importance for Australia of ocean-based activities is already large and the potential immense. Major discoveries arising from research in the last few years provide great promise and indicate the importance of adequately funded research. If past abuses are to be corrected and future abuse avoided, there is urgent need to develop a program of multiple use management. If the commercial, aesthetic, cultural and conservation values of our marine environment are to be realised, funding for the necessary research must be provided now. [Ed.]
\end{abstract}

Key Words: ocean, marine resources, marine research, tourism, sustainable development, oceans policy, Tasmania, Australia.

In the 15th century the nations of Europe discovered the deep sea. It was an alien and forbidding place that seemed to offer little but danger. The coastal waters were rich with fish and other marinelife. Within sight of the European coastline there was an abundance of seafood. There was no need to fish unknown and inhospitable waters, and what else was out there except dragons, demons and angry gods?

Yet the nations of Europe prospered in direct proportion to their mastery of the open sea. Spain and Portugal amassed stunning wealth and virtually ruled the world, because they perfected the arts of navigation and seamanship.

Today the world is facing a similar situation. The ocean holds out a promise of wealth and prosperity to those nations that will learn how to work with her in harmony. That is why the Australian Marine Industries and Sciences Council, in its 1997 report, said :

marine areas are seen by many as one of the last relatively unexplored resources and frontiers for industry development. Consequently, countries, which develop leading edge marine industries or technologies, have the potential to supply a very wide international demand.

What could be more natural than to see a great island nation like Australia, a nation that worships her oceans, develop this national attribute into a source of broad economic strength? It would seem to be the most natural thing in the world, but it may not happen unless we begin to get serious about understanding our oceans.

The oceans are virtually untapped resources. Today we stand before the oceans as our ancient ancestors once stood before the land, as mere hunter-gatherers, only beginning to understand the power to be released by the secrets of farming, husbandry, harvesting and mining within a vital new resource. How far back must we look to find the time when we knew as little about how to use the land, when we were only beginning to understand the rudiments of agriculture and husbandry?

There are two reasons why marine research is vital to our future. First, it is needed in order to make the most of our marine opportunities. Second, it is essential in order to understand and monitor environmental reactions and to ensure that marine resources are developed in a responsible and sustainable manner.
The marine operating environment is both hostile and sensitive. Marine industries develop through improved knowledge of the resource, through technical innovation and development, and through better knowledge of the operating environment. Research is vital to this process.

When we say that there are large rewards to be gained through understanding and accessing ocean resources what do we mean? Are we talking really big sums? Are we talking about something that is worth more to us than wool, or wheat, or coal or oil and gas?

Yes! In fact, right now marine resources earn Australia more than all her agricultural production, both livestock and crop, and all the flow-on industries that support agriculture. Furthermore, marine resources are growing at a rate two to three times the annual growth rate of our economy. Marine resources are big and rapidly getting bigger.

In 1984 our marine resources were worth about $\$ 16$ billion a year, today they are worth about $\$ 52$ billion, by 2020 they will exceed $\$ 120$ billion a year. Australia's marine resources are growing so rapidly they represent one of the most buoyant sectors of the economy and a major area for new industry and job creation.

It is always rather difficult to pin down earning from marine resources, since marine resource are not seen as a separate area when compiling Australia's economic statistics. Anyone questioning our estimates for current marine resource earnings will find the following research into marine tourism enlightening.

The Bureau of Tourism Research reported that marine tourism is a significant proportion of Tourism in Australia, comprising $50 \%$ of international visits and $42 \%$ of domestic visits.

The Department of Industry, Science and Tourism commissioned a report on the impact of coastal and marine tourism, based on information obtained from 44 geographical regions that comprise coastal areas around Australia. Only non-business visitors were included in the survey.

The survey found that, in 1995-96, expenditure on coastal and marine tourism was $\$ 23$ billion. This represents $3 \%$ of Australia's total expenditure on goods and services. When the flow-on effects are added, the total expenditure attributable to marine tourism is $\$ 36$ billion a year, or $5 \%$ 
of the Australian total for goods and services. This also represents $5 \%$ of the Australian full-time equivalent workforce, $5 \%$ of total Australian wages and 5\% of Australia's gross domestic product.

Matine tourism is a very large portion of Australia's economy and is directly interrelated with other industries within the marine resource area, such as commercial fishing, aquaculture, shipping, oil, gas and seabed mining. The continued success of our marine tourism is linked to the sustainable use of the total marine resource, and could be seriously damaged by abuse of our oceans.

Darnage through unsustainable use of marine resources may threaten the earning power of the whole marine area, which currently represents $6.5 \%$ of the gross national product and is the most vigorously growing sector of the Australian economy.

The entire marine resource area breaks down in this manner:

- tourism
- oil and gas
- shipping
- fisheries \& aquaculture
- other and boat building
- total

- tourism

- oil and gas

- ship and boat building

- total
Everyone wants and needs the knowledge that marine research provides. Without such knowledge, governments cannot make environmentally sound decisions. Ocean industries, from tourism to oil and gas, need access to the commonly held marine resource before they can produce income. They know that without the knowledge provided by marine research, the environmental lobby must push for an extremely cautious approach. Adequate marine research is in everyone's best interest.

Environmentalists, marine industries, scientists and the general public are all solidly behind the sustainable development of our ocean resources. The only way this can be achieved is through scientific and technical information employed in a program of multiple-use management. In this manner, the great economic benefits that are flowing from our marine resources can be accessed in the best possible manner.

Australia, under the United Nations Law of the Sea, is responsible for the third largest marine territory in the world. This marine territory will be the source of great economic benefit to Australia, but we are committed to developing it in an environmentally sustainable manner. It is important that we meet that international commitment. It is important that we do not make the same mistakes with the oceans that we made in developing the land.

Despite the rapid growth potential of our ocean resources, we know very little about our marine territory. We do not know enough to manage its development in a responsible manner. Within our ocean territory Australia has access to resources that include food, pharmaceuticals, minerals, oil and gas, and the use of the oceans for tourism, transport and recreation. Less than $5 \%$ of this marine territory has been physically mapped. Less than $2 \%$ has been mapped in terms of its habitat. We cannot begin to manage a resource, when we do not even know what is there to be managed.

We have little time. Because the benefits offered by our marine resources are so rich, development will take place. Unless our marine research program is stepped up, that development will take place without the knowledge needed to builded this resource in a responsible, sustainable manner. We will misuse our oceans just as we did our land. This time we will not do so out of ignorance - because we do know better. We will repeat our mistake simply through lack of resolve.

How little time do we have? CSIRO Marine Research has developed an amazing ability to fast-track the mapping of ocean habitat. We have the techniques to map $10000 \mathrm{~km}^{2}$ of ocean in two weeks, but we don't have the ships to do this.

If we had a ship devoted full time to this task we would finish the job in about 110 years. By that time the environmental disasters will have already occurred. Our Oceancare program will be well established, spending billions of dollars a year to correct our blunders.

But CSIRO Marine Research doesn't have a ship that can be devoted, full time, to such mapping. So it is unlikely that we will ever have the information needed to develop our ocean resources in a sustainable manner. If more resources could be devoted to such projects, and if areas of development were mapped first, it might be possible to keep pace with the rate of development.

If nothing is done, we will not have sufficient knowledge to ensure the sustainable, multiple-use management of ocean resources. This will make development decisionmaking, without hard information, tortuous. It will throw developers into wasteful, drawn-out media and legal battles, adding to the cost of all development. It will place regulatory agencies in the unenviable position of being forced into decisions they cannot support with firm data. They will be vulnerable to criticism no matter what decision they make. Our policy will be decided in the media and in the courtroom, and marine development will be slow and needlessly expensive.

How much are we spending now, through agencies such as Landcare, to reverse the mistakes we have made in the management of the land? Despite all the expenditure, how many of those mistakes are actually reversible? How does this expenditure compare with the funding to understand and manage our marine resources?

The Commonwealth Government supports Landcare projects that contribute to the sustainable management of land, water, vegetation and biological diversity. Each year $\$ 280$ million is committed from the Natural Heritage Trust to Landcare. An additional 50\%, \$1 for each $\$ 2$ spent by the Government, is allocated by more than 4000 Landcare groups across Australia. Funding is also made available locally and through state agencies.

Funding is complemented by Commonwealth support for Landcare activities, provided through a range of related grants, programs and tax concessions. New tax rebate and credit arrangements are being made available to encourage further investment in on-farm Landcare works.

In total, something like half a billion dollars a year is spent in trying to redress the mistakes we have made in managing the land. If we include tax deduction for Landcare activities, this may come closer to a billion dollars a year. In comparison, very little is spent to avoid making the same mistakes on the oceans.

Failure to act may cost us dearly, in terms of economic opportunity and the eventual cost of correcting our mistakes, but it may also have dire consequences in terms of our quality of life on the planet Earth. The vast and deep expanse of ocean that covers $70 \%$ of our planet is massive, 
and slower to change than the atmosphere. The ocean acts as a regulator to stabilise many aspects of conditions on the Earth, such as climate.

Many environmental abuses, to which we have subjected our planet, have been soaked up and tempered by our oceans. Their impact is reduced by the resistance of the oceans to rapid change.

Although the stability of the ocean gives us latitude, it will not be endlessly forgiving. When we begin to affect the nature of the great ocean cycles, retribution will be fast and dramatic, and the process will be equally slow and difficult to reverse. It is important that we know how profoundly the oceans have been affected by out neglect, and how they are likely to react to it.

With the promise of so much before us, with so much to learn, so much to do, what are we, as a nation, actually doing? How are we to come to know and understand this ocean world for which we are responsible, which we are committed to manage well, and which promises so handsome a return on our investment?

We certainly mean well. The International Year of the Ocean, in 1998, gave us Australia's Oceans Policy, one of the world's first attempts at providing the kind of guidance needed in order to ensure sustainable use of valuable ocean resources.

Now we must find the way to turn policy into useful action. The ocean policy must be backed by the funding to make it work. It must include the kind of research funding needed to allow us to use our ocean resources safely and well.

Implementation of the policy must recognise marine resources as a special economic sector with needs of its own. At the moment there are not even any economic statistics kept on ocean resources. Fishing and aquaculture are considered to be a part of agriculture. Offshore oil and gas, or offshore mining are just a part of the mining statistics. Shipping is part of transport, marine tourism part of tourism, and so forth.

This is not good enough. All these areas are dependent upon access to our oceans. They affect our oceans, they affect other marine industries, they are closely linked and interrelated. Sustainable development of our marine resources depends upon a carefully devised multiple-use management program, based on scientific monitoring and research.
The people of Australia are proud of her wonderful oceans, as they should be. Although threatened, Australia's coastal and continental shelf waters are far better preserved than those in most of the world. And they are unique, as are the marine creatures that live there. The waters of the Southern Hemisphere contain many surprises for us.

In just the past five or six years, a volcanic province the size of Iceland was discovered off the Western Australian coast, and a cluster of deep-sea volcanoes, rising higher off the seabed than any of Australia's mountains, was found off Tasmania. In the last year, during routine sea exploration, a gas hydrate field was discovered off Lord Howe Island that has more energy potential then the Northwest Shelf. Such discoveries highlight the frontier nature of marine science in Australian waters.

What of biodiversity? We have an estimated $11 \%$ of the world's marine species, many of which are unique to our water. In the past decade, over 800 new species of fish have been identified in our marine territory. In one CSIRO survey of the deep-ocean seamounts $80 \mathrm{~km}$ south of Tasmania, new species were found in virtually every animal group, from corals and hydroids to crabs and fish.

A study on the Great Barrier Reef, by the Queensland Museum, found more than 4000 new species of sponges. Surveys conducted on Australia's upper continental slope have already found more than twice the number of species found on similar slopes in the Atlantic, even after decades of extensive survey work by American and European scientists.

Full realisation of the commercial, aesthetic, cultural and conservation values of our marine environment can only be achieved with proper understanding of how the marine systems work. This requires a bold and determined focus on marine research delivered and sustained by an ocean policy of true power and vision. We must insist on no less.

\section{BIBLIOGRAPHY}

Commonwealth of Australia, 1998: AUSTRALIA'S OCEANS POLICY 1 \& 2. Environment Australia.

HoOper, J.N.A. (Ed.): PROCEEDINGS OF THE 5TH INTERNATIONAL SPONGE SYMPOSIUM. Mem. QId Mus. 44.

Koslow, J.A. \& GowletT HOLMES, K., 1998: THE SEAMOUNT FAUNA OF SOUTHERN TASMANIA. FRDC Project 95/058. Final reporr to Environ. Ausr. \& Fish. Res. Dev. Corp. CSIRO/FRDC/Environment Australia. 